\title{
PENGARUH PERSEPSI NEGARA ASAL TERHADAP NIAT BELI ULANG DIMEDIASI OLEH EKUITAS MEREK
}

\author{
I Komang Satria Warla Putra ${ }^{1}$ \\ Putu Yudi Setiawan ${ }^{2}$ \\ Ni Nyoman Rsi Respati ${ }^{3}$ \\ ${ }^{1,2,3}$ Fakultas Ekonomi dan Bisnis Universitas Udayana, Bali, Indonesia \\ 1e-mail: satriawarla@gmail.com
}

\begin{abstract}
ABSTRAK
Seorang pelanggan dalam memeutuskan niat untuk membeli kembali ditentukan oleh berbagai faktor, seperti citra negara asal dan ekuitas suatu merek. Tujuan penelitian ini adalah untuk mengetahui pengaruh persepsi negara asal terhadap niat beli ulang dimediasi oleh ekuitas merek. Penelitian ini dilakukan terhadap pelanggan smartphone merek Xiaomi di Kota Denpasar. Jumlah sampel yang diambil sebanyak 120 orang, dengan metode non-probability sampling, khususnya purposive sampling Pengumpulan data dilakukan melalui kuesioner. Data yang telah dikumpulkan diukur dengan skala likert dengan skala 1-5. Teknik analisis yang digunakan adalah Partial Least Square (PLS). Berdasarkan hasil analisis menunjukkan bahwa semua hipotesis diterima. Negara asal berpengaruh positif dan signifikan terhadap ekuitas merek, Ekuitas merek berpengaruh positif dan signifikan terhadap niat beli kembali, negara asal berpengaruh positif dan signifikan terhadap niat beli kembali dan ekuitas merek mampu memediasi pengaruh negara asal terhadap niat beli ulang smartphone merek Xiaomi di Kota Denpasar.
\end{abstract}

Kata kunci: Negara asal, ekuitas merek, niat beli ulang, smartphone Xiaomi

\begin{abstract}
A customer in determining the intention to repurchase is determined by various factors, such as the image of the home country and the equity of a brand. The purpose of this study was to determine the effect of the perception of the country of origin on repurchase intention mediated by brand equity. This research was conducted on Xiaomi brand smartphone customers in Denpasar City. The number of samples taken as many as 120 people, with the method of nonprobability sampling, especially purposive sampling Data collection is done through a questionnaire. The collected data is measured by Likert scale with scale 1-5. The analysis technique used is Partial Least Square (PLS). Based on the results of the analysis shows that all hypotheses are accepted. The country of origin has a positive and significant impact on brand equity. Brand equity has a positive and significant effect on the repurchase intention, the country of origin has a positive and significant impact on the repurchase intention and the brand equity is able to mediate the influence of the country of origin on the intention to repurchase the Xiaomi brand smartphone in Denpasar City.
\end{abstract}

Keywords: Country of origin, brand equity, repurchase intention, Xiaomi smartphone 


\section{PENDAHULUAN}

Tingginya tingkat pertumbuhan penggunaan smartphone berkaitan dengan semakin banyaknya permintaan akan smartphone baru. Tingkat penetrasi yang cepat menimbulkan pertanyaan mengapa tingkat pertumbuhan adopsi smartphone sudah begitu tinggi dan fitur apa yang membuat orang tertarik terhadap alat/smartphone baru (Kim et al.,2014). Perkembangan zaman menuntut produsen smartphone untuk berlomba-lomba memenuhi kebutuhan dan tuntutan pasar.

Informasi negara asal suatu produk digunakan sebagai dasar atau patokan dalam melakukan keputusan pembelian (Sanyal dan Datta, 2011). Konsumen dalam melakukan keputusan pembelian pada umumnya didasarkan atas kualitas, iklan, distribusi, dan harga, perkembangan zaman menciptakan evolusi pada pemikiran konsumen, saat ini konsumen juga mempertimbangkan faktor lain seperti negara asal suatu produk (Abdi, 2010). Banyak produk yang telah terkenal citra negara asalnya seperti mobil dari Jerman, pakaian dan parfum dari Perancis serta smartphone yang saat ini dari China.

Merek Xiaomi berada pada peringkat 5 di dunia. Mereka juga berpendapat alasan membeli smartphone merek Xiaomi yang merupakan produk asal China karena harganya relatif rendah namun memiliki kualitas/spesifikasi yang tinggi. Pertimbangan konsumen terhadap negara asal, mempengaruhi evaluasi-evaluasi selanjutnya mengenai produk tersebut dan mempengaruhi konsumen untuk melakukan niat beli kembali (Permadi, 2011). Namun, smartphone merek Xiaomi walaupun sudah terkenal 
di masyarakat tetap saja masih terkalahkan oleh perusahaan pesaingnya yang telah lebih dulu menguasai pasar seperti Oppo, Apple dan Samsung.

Apabila konsumen ingin mencari spesifikasi smartphone yang mumpuni dengan harga terjangkau serta fitur yang lengkap, maka konsumen akan memilih merek Xiaomi. Namun, apabila konsumen menginginkan smartphone yang memiliki kepastian, kualitas, serta purna beli yang baik konsumen akan lebih beralih ke merek lain seperti Samsung (Andy, 2017).

Pada masa ini konsumen selalu ingin memperbarui produk gadgetnya, selain mampu memberikan efisiensi, juga karena teknologi yang terus berkembang, produk gadget terbaru juga digunakan sebagai barang untuk mengikuti perkembangan zaman/tren. Keputusan pembelian kembali secara khusus, mungkin kurang terkait dengan faktor individu / pribadi, tapi lebih didorong oleh konstruksi sosial dan budaya seperti orientasi kelompok atau kebutuhan meningkatkan reputasi mereka di depan orang lain (Filieri et al.,2017). Memperbarui gadget dapat dilakukan dengan cara membeli kembali produk smartphone yang memiliki ekuitas merek terbaik di benak konsumen. Konsumen puas ketika harapan mereka mengenai kinerja produk pada saat sebelum membeli, dipenuhi oleh pengalaman aktual mereka menggunakan produk saat pasca pembelian (Filieri et al.,2017). Akhirnya, keputusan mereka untuk membeli kembali produk yang sama dan layanan dipengaruhi oleh tingkat kepuasan mereka.

Xiaomi merupakan perusahaan baru yang masuk pasar smartphone namun mampu bertahan menyaingi pesaing seniornya. Walaupun Xiaomi memiliki kelemahan seperti 
I Komang Satria Warla Putra, Pengaruh Persepsi Negara...

layanan purna jualnya yang kurang, namun dengan harga yang terjangkau dan spesifikasi yang tinggi mampu menjadi keunggulan bagi smartphone merek Xiaomi. Sejak merilis smartphone pertamanya di Indonesia pada bulan September 2014, Xiaomi terus berkembang hingga sekarang pada pasar smartphone Indonesia (Pratomo, 2014).

Efek dari negara asal produsen akan berbeda dalam kasus baik produk keterlibatan rendah maupun tinggi. Efek ini mungkin lebih terasa dalam kasus negara-negara berkembang dimana ketersediaan informasi mungkin berbeda dari yang dapat ditemukan di negara maju (Tabassi et al.,2013). Berdasarkan penemuan ini pengaruh negara asal dapat berbeda tergantung dari ketersediaan informasi dari negara tersebut. Penelitian ini didukung dengan pentingnya citra negara asal secara umum sebagai alat untuk penuntun evaluasi produk konsumen dan niat perilaku terhadap niat beli kembali (Josiassen et al.,2009). Ulfah (2017) mengatakan bahwa, Negara asal memiliki peran yang signifikan terhadap niat beli kembali. Ini bertolak belakang dengan hasil penelitian yang dilakukan oleh (Ghalandari et al.,2012), menunjukkan bahwa pengaruh negara asal produksi dengan keinginan membeli kembali individu yang memiliki pengetahuan subjektif rendah dan tinggi terhadap produk tidak berpengaruh langsung terhadap niat beli kembali.

Penelitian ini menambahkan ekuitas merek sebagai variabel mediasi untuk membantu memperjelas hubungan antara negara asal terhadap niat beli kembali. Penelitian ini didukung dengan hasil penelitian dari Permadi (2011) yang menemukan bahwa ekuitas merek memiliki peran signifikan dalam memediasi negara asal terhadap 
niat beli kembali. Ulfah (2017) juga menyatakan bahwa, ekuitas merek memiliki peran signifikan dalam memediasi pengaruh negara asal terhadap niat beli kembali.

Citra negara asal telah mempengaruhi ekuitas merek secara positif dan signifikan (Panda et al., 2014). Ekuitas merek berhubungan dengan negara asal, pandangan konsumen akan negara asal mengingatkan identitas dan kelebihan dari merek tersebut. Efek potensial dari nama negara pada proses pasar secara positif atau negatif dapat dinilai sebagai "efek distorsi" karena akan menentukan proses pengambilan keputusan rasional (Saydan, 2013).

Ekuitas merek merupakan nilai tambah yang diberikan pada produk dan layanan. Suatu merek dapat tercermin di benak konsumen, yang dirasakan, harga, pangsa pasar, dan profitabilitas dari merek suatu merek dapat dikatakan sebagai ekuitas merek (Kotler dan Keller, 2012:243). Merek yang kuat membantu perusahaan membangun sebuah identitas di pasar. Ekuitas merek adalah hasil dari konsumen. Akumulasi dari pengalaman dan pengetahuan konsumen terhadap suatu merek merupakan faktor yang dapat mempengaruhi konsumen untuk melakukan pembelian kembali merek yang sama (Setyaningsih et al., 2007).

Pemasar global tahu bahwa pembeli memiliki sikap dan kepercayaan yang berbeda tentang merek atau produk dari berbagai negara. Persepsi ini bisa menjadi atribut dalam membuat keputusan atau mempengaruhi atribut lain dalam prosesnya (Kotler dan Keller, 2012:614). 
Konsumen mengembangkan minat dan preferensi merek berdasarkan persepsi mereka, negara asal dan informasi yang tersedia untuk merek. Informasi yang menguntungkan tentang negara membantu menciptakan sikap positif terhadap merek, yang mengarah pada citra merek yang menguntungkan (Yasin et al., 2012). Yasin melanjutkan konsumen memiliki pandangan yang berbeda terhadap produk yang dibuat dari negara yang berbeda-beda.

Salah satu aset tak berwujud yang paling berharga dari sebuah perusahaan adalah mereknya. Ekuitas merek tercermin di benak konsumen, dirasakan, bertindak berkenaan dengan merek, harga, pangsa pasar, dan profitabilitas merek (Kotler dan Keller, 2012:243). Ekuitas merek memberikan keunggulan kompetitif yang berkelanjutan karena menciptakan hambatan kompetitif yang berarti. Ekuitas merek dikembangkan melalui peningkatan persepsi kualitas, loyalitas merek, dan kesadaran merek / asosiasi merek, tidak bisa dibangun atau hancur dalam jangka pendek tapi hanya bisa dibangun dalam jangka panjang melalui investasi pemasaran yang dirancang dengan cermat (Yoo et al., 2000).

Produk memiliki ekuitas merek positif ketika konsumen bereaksi lebih baik terhadap produk dan cara pemasarannya dipasarkan secara jelas. Ekuitas merek negatif jika konsumen bereaksi kurang baik terhadap aktivitas pemasaran untuk merek dalam situasi yang sama (Kotler dan Keller, 2012:244). Merek yang kuat dapat menjadi keunggulan kompetetif bagi perusahaan untuk jangka panjang. Menurut Aaker (2014).

Konsumen memiliki tujuan pembelian ulang terhadap suatu produk dengan merek tertentu, saat itu secara tidak langsung konsumen tersebut telah memiliki 
perilaku loyal serta rasa puas terhadap merek itu, sehingga menurut Pather, 2017 kecenderungan untuk merekomendasikan merek atau perusahaan kepada orang lain merupakan komitmen untuk menolak beralih ke produk pesaing. Keputusan untuk niat beli kembali menunjukkan pilihan konsumen terhadap produk secara berulang. Niat pembelian kembali berarti pelanggan menggunakan respon tertentu setelah melakukan evaluasi produk secara keseluruhan dan niat masa depannya.

Negara asal suatu merek memberikan pandangan bagi konsumen mengenai ekuitas merek yang diproduksi pada negara bersangkutan. Panda dan Misra (2014) dalam penelitiannya terhadap produk tahan lama di India menyatakan bahwa negara asal memiliki hubungan yang positif dan signifikan terhadap ekuitas merek. Shahrokh dan Azodi (2013) dalam penelitiannya terhadapa konsumen Iran smartphone juga menemukan bahwa negara asal berdampak positif dan signifikan terhadap ekuitas merek didukung oleh penelitian Saydan (2013) menemukan hasil yang sama. Ekuitas merek suatu produk dapat berdampak postif terhadap citra negara, dengan asumsi bahwa ekuitas merek memiliki peran dalam mempengaruhi citra negara dalam sebuah produk, dapat dirumuskan sebagai berikut:

$\mathrm{H}_{1}$ : Negara asal berpengaruh positif dan signifikan terhadap ekuitas merek

Pelanggan akan memiliki minat untuk melakukan pembelian ulang apabila ekuitas merek dari produk yang telah dibeli memberikan kesan yang baik. Menurut Chen (2011) dan Pather (2017) menemukan bahwa ekuitas merek berpengaruh positif dan signifikan terhadap niat beli kembali. Said (2014) dalam penelitiannya yang 
I Komang Satria Warla Putra, Pengaruh Persepsi Negara...

dilakukan terhadap konsumen smartphone Nokia di Malaysia mengemukalam bahwa ekuitas merek berpengaruh terhadap niat beli kembali. Didukung dengan temuan dari Lin (2011) yang menemukan dampak dari ekuitas merek, brand attachment, keterlibatan produk dan niat membeli kembali pada pengguna sepeda pada industri Taiwan.. Berdasarkan beberapa hasil penelitian sebelumnya maka dapat dirumuskan hipotesis sebagai berikut:

$\mathrm{H}_{2}$ : Ekuitas merek berpengaruh positif dan signifikan terhadap niat beli kembali Pelanggan menilai negara asal produk dijadikan sebagai pertimbangan untuk membeli kembali. Menurut hasil penelitian dari Filieri et al. (2016) terhadap pengguna smartphone di China menemukan bahwa terdapat pengaruh positif dan signifikan negara asal terhadap niat beli kembali. Aulia (2016) juga menemukan adanya hubungan antara negara asal dan niat beli kembali dalam penelitiannya terhadap konsumen Taiwan mengenai niat beli kembali produk kecantikan Korea. Penemuan ini diperkuat dengan hasil dari Josiassen (2009) yang menyatakan bahwa negara asal berpengaruh positif dan signifikan terhadap niat beli kembali. Jadi rumusan hipotesis yang dapat diajukan dalam penelitian ini yaitu:

$\mathrm{H}_{3}$ : Negara asal berpengaruh positif dan signifikan terhadap niat beli kembali

Ekuitas merek menjadi penghubung antara citra negara asal suatu produk terhadap minat pelanggan untuk membeli kembali. Berdasarkan hasil temuan Ghalandari et al. (2012) yang menunjukkan bahwa negara asal tidak berpengaruh langsung terhadap niat beli kembali, tergantung dari seberapa besar pengetahuan yang 
dimiliki konsumen dan kekuatan pemasaran menginformasikan produk. Permadi (2011) dalam penelitian yang dilakukannya di Solo terhadap elektronik buatan Jepang menyatakan peran ekuitas merek dalam memediasi negara asal terhadap niat beli kembali. Ulfah (2017) juga menemukan bahwa ekuitas merek memiliki peran yang signifikan dalam memediasi negara asal terhadap niat beli kembali. Berdasarkan hasil penelitan ini, rumusan hipotesis yang dapat diajukan yaitu:

$\mathrm{H}_{4}$ : Peran ekuitas merek memediasi pengaruh negara asal terhadap niat beli ulang

\section{METODELOGI PENELITIAN}

Penelitian ini dilakukan di Kota Denpasar. Lokasi ini dipilih karena Kota Denpasar memiliki daya beli masyarakat yang tinggi dengan jumlah pasar potensial cukup besar. Menurut Badan Pusat Statistik Tahun 2015 Denpasar memiliki kepadatan penduduk terbesar di antara kota yang ada di Provinsi Bali yaitu sebesar 6891.5 juta jiwa, diikuti Badung 1472.8 juta jiwa dan Gianyar 1345.4 juta jiwa. Mobilitas masyarakat yang tinggi membutuhkan salah satunya smartphone sebagai alat penunjang dalam beraktifitas. Variabel bebas dalam penelitian ini adalah negara asal yang disimbolkan dengan (X). Variabel terikat dalam penelitian ini adalah niat beli kembali yang disimbolkan dengan (Y). Variabel mediasi dalam penelitian ekuitas merek yang disimbolkan dengan (M).

Populasi dalam penelitian ini adalah pengguna smartphone merek Xiaomi di Kota Denpasar yang tidak diketahui jumlahnya dengan pasti. 
Penelitian ini menggunakan metode penentuan sampel non probability sampling yaitu teknik pengambilan sampel tidak secara acak sehingga setiap elemen populasi mempunyai probabilitas yang berbeda untuk dipilih menjadi sampel (Rahyuda et al., 2016:138). Teknik non probability sampling yang dipilih adalah purposive sampling yaitu teknik penentuan sampel dengan pertimbangan tertentu. Kriteria penentuan sampel dalam penelitian ini adalah sebagai berikut: 1) Pelanggan yang sudah pernah membeli produk smartphone merek Xiaomi. 2) Minimal 17 tahun. Dengan asumsi bahwa responden dengan umur minimal 17 tahun dapat memahami dan mampu menjawab kuesioner secara objektif karena sudah memiliki KTP. 3) Berdomisili di Kota Denpasar

Menurut Sugiyono $(2015,165)$, jika dalam penelitian menggunakan multivariate dalam melakukan analisis, maka jumlah anggota sampel minimal 5 sampai 10 kali dari jumlah variabel yang akan diteliti. Jika formula ini digunakan maka ukuran sampel berada pada rentang 60 sampai dengan 120. Jumlah responden yang menjadi anggota sampel dalam penelitian diambil yang maksimal yaitu 120 orang.

Data dikumpulkan dengan metode survei yaitu menyebarkan kuisioner kepada responden secara langung. Penelitian ini dilakukan dengan cara penyebaran kuesioner secara online.

Dalam penelitian ini, data kuantitatifnya adalah jumlah responden, usia responden, pangsa pasar penyebaran smartphone serta pertumbuhan penduduk. Data kualitatif dalam penelitian ini adalah jawaban responden terhadap indikator variabel, jenis kelamin responden, serta pekerjaan responden. Sumber primer dalam penelitian 
ini adalah responden yang menjadi anggota sampel. Sumber sekunder dalam penelitian ini adalah lembaga atau instansi terkait seperti survey Gallup, International Data Corporation (IDC), berita online dan studi empiris yang mempublikasikan data berkaitan dengan penelitian ini.

Data dalam analisis ini menggunakan statistik deskriptif dan statistik inferensial. Statistik deskriptif berupa data seperti usia, jenis kelamin, pekerjaan dan rata-rata hitung yang digunakan untuk mengolah data. Statistik inferensial merupakan metode yang digunakan dalam penelitian ini yaitu PLS (Partial Least Square).

Penelitian ini menggunakan metode analisis data dengan menggunakan software SmartPLS versi 2.0 yang dijalankan dengan media komputer. PLS (Partial Least Square) merupakan analisis persamaan struktural (SEM) berbasis varian yang secara simultan dapat melakukan pengujian model pengukuran sekaligus pengujian model struktural. Model pengukuran digunakan untuk uji validitas dan reabilitas, sedangkan model struktural digunakan untuk uji kausalitas atau pengujian hipotesis dengan model prediksi (Hussein,2015).

Uji Sobel digunakan untuk menguji signifikansi dari hubungan tidak langsung antara variabel eksogen dengan variabel endogen yang dimediasi oleh variabel intervening dapat menggunakan uji sobel. Suatu variabel disebut variabel mediasi jika variabel tersebut ikut memengaruhi hubungan antara variabel bebas dan variabel terikat (Ghozali, 2013). Uji Sobel dapat dirumuskan dengan menggunakan persamaan sebagai berikut: 


$$
Z=\frac{a b}{\sqrt{a^{2} s_{b}^{2}+b^{2} s_{a}^{2}+s_{a}^{2} s_{b}^{2}}} \ldots \ldots \ldots \ldots \ldots \ldots \ldots(1)
$$

Keterangan:

$Z$ = nilai kalkulasi sobel.

$\mathrm{a}=$ koefisien regresi dari variabel eksogen $(\mathrm{X})$ terhadap variabel intervening (M).

$\mathrm{s}_{\mathrm{a}}=$ standard error dari $\mathrm{a}$.

$\mathrm{b}=$ koefisien regresi variabel intervening $(\mathrm{M})$ terhadap variabel endogen $(\mathrm{Y})$.

$\mathrm{S}_{\mathrm{b}}=$ standard error dari $\mathrm{b}$.

Bila nilai kalkulasi Z lebih besar dari 1,96 (dengan tingkat kepercayaan 95\%), maka variabel intervening dinilai secara signifikan memediasi parsial pengaruh antara variabel eksogen dengan variabel endogen.

\section{HASIL PENELITIAN DAN PEMBAHASAN}

Hasil karakterisitik pendidikan terakhir responden memperlihatkan bahwa pendidikan terakhir responden terbanyak adalah pendidikan SMA sebanyak 52 orang dengan persentase 43,3 persen dibandingkan dengan yang lainnya. Hasil tersebut menunjukkan bahwa pendidikan terakhir pada tingkat SMA berindikasikan lebih tinggi melakukan pembelian ulang. Hal ini dikarenakan pendidikan SMA sudah memiliki pengetahuan yang cukup luas untuk memahami spesifikasi smartphone.

Hasil karakterisitik usia responden memperlihatkan bahwa responden dengan usia terbanyak adalah responden dengan usia 17-23 tahun sebanyak 44 orang dengan persentase 36,7 persen dibandingkan dengan kelompok usia lainnya. Hasil tersebut menunjukkan bahwa pada usia 17-23 tahun konsumen lebih cenderung untuk 
melakukan pembelian ulang. Sesuai dengan pendidikan SMA yang lebih banyak berada pada rentang usia tersebut.

Hasil karakterisitik jenis kelamin responden memperlihatkan responden dengan jenis kelamin laki-laki lebih banyak dibandingkan dengan responden perempuan. Hasil tersebut menunjukkan bahwa laki-laki lebih berindikasikan melakukan pembelian ulang terhadap produk smartphone merk Xiaomi di Kota Denpasar. Hal ini dikarenakan laki-laki lebih memiliki pengetahuan tentang spesifikasi produk smartphone dibandingkan dengan perempuan. Dilihat dari penggunaan smartphone sehari-hari, perempuan lebih melihat dari tampilan produk.

Hasil karakterisitik pekerjaan responden dalam kuesioner penelitian memperlihatkan bahwa responden dengan pekerjaan sebagai pelajar atau mahasiswa merupakan responden terbanyak dengan jumlah responden sebanyak 58 orang dengan persentase 48,3 persen dibandingkan dengan yang lainnya. Hasil tersebut menunjukkan selaras dengan rentangan usia responden yang menggunakan smartphone merek Xiaomi di Kota Denpasar.

Validitas model dibahas terlebih dahulu, sebelum membahas signifikansi pengaruh langsung masing-masing variabel eksogen terhadap variabel endogen dalam model penelitian. Terdapat tiga kriteria didalam penggunaan teknik analisis data dengan Smart PLS untuk menilai outer model yaitu convergent validity, discriminant validity, serta average variance extracted (AVE) (Ghozali, 2013). Outer model dinilai dengan cara melihat convergent validity (besarnya loading factor untuk masing- 
I Komang Satria Warla Putra, Pengaruh Persepsi Negara...

masing konstruk). Penelitian ini menggunakan batas minimal loading factor sebesar 0,5 .

Tabel 1.

Outer Loadings

\begin{tabular}{lccc}
\hline & Ekuitas Merek & Negara Asal & Niat Beli Ulang \\
\hline M.1.1 & 0.858858 & & \\
M.1.2 & 0.831486 & & \\
M.1.3 & 0.828396 & & \\
M.1.4 & 0.787197 & 0.853348 & \\
X.1.1 & & 0.826389 & \\
X.1.2 & & 0.855156 & \\
X.1.3 & & 0.837716 & 0.861082 \\
X.1.4 & & & 0.825200 \\
Y.1.1 & & & 0.839168 \\
Y.1.2 & & & 0.840766 \\
Y.1.3 & & & \\
Y.1.4 & & &
\end{tabular}

Sumber: Data diolah, 2018

Hasil pengolahan pada Tabel 1. memperlihatkan bahwa nilai outer model telah memenuhi kriteria convergent validity, semua indikator memiliki loading factor di atas 0,50. Dapat disimpulkan bahwa konstruk mempunyai convergent validity yang baik.

Discriminant validity dari model pengukuran dengan reflektif indikator dinilai berdasarkan cross loading pengukuran dengan konstruk. Jika korelasi konstruk dengan item pengukuran lebih besar daripada ukuran konstruk lainya, maka hal ini menunjukkan bahwa konnstruk laten memprediksi ukuran pada blok mereka lebih baik daripada ukuran pada blok lainnya. 
Tabel 2.

Cross Loadings

\begin{tabular}{lccc}
\hline & Ekuitas Merek & Negara Asal & Niat Beli Ulang \\
\hline M.1.1 & $\mathbf{0 . 8 5 8 8 5 8}$ & 0.621758 & 0.574245 \\
M.1.2 & $\mathbf{0 . 8 3 1 4 8 6}$ & 0.563990 & 0.593444 \\
M.1.3 & $\mathbf{0 . 8 2 8 3 9 6}$ & 0.618453 & 0.635361 \\
M.1.4 & $\mathbf{0 . 7 8 7 1 9 7}$ & 0.590236 & 0.590643 \\
X.1.1 & 0.590936 & $\mathbf{0 . 8 5 3 3 4 8}$ & 0.535527 \\
X.1.2 & 0.538425 & $\mathbf{0 . 8 2 6 3 8 9}$ & 0.520758 \\
X.1.3 & 0.678663 & $\mathbf{0 . 8 5 5 1 5 6}$ & 0.535971 \\
X.1.4 & 0.626270 & $\mathbf{0 . 8 3 7 7 1 6}$ & 0.608997 \\
Y.1.1 & 0.601508 & 0.536317 & $\mathbf{0 . 8 6 1 0 8 2}$ \\
Y.1.2 & 0.540443 & 0.464762 & $\mathbf{0 . 8 2 5 2 0 0}$ \\
Y.1.3 & 0.618554 & 0.558908 & $\mathbf{0 . 8 3 9 1 6 8}$ \\
Y.1.4 & 0.664938 & 0.624250 & $\mathbf{0 . 8 4 0 7 6 6}$ \\
\hline
\end{tabular}

Sumber: Data diolah, 2018

Data pada Tabel 2. menjelaskan bahwa nilai cross loading menunjukkan adanya discriminant validity yang baik. Hal tersebut dapat dilihat dari nilai korelasi indikator terhadap konstruknya (loading factor) lebih tinggi dibandingkan nilai korelasi indikator tersebut dengan konstruk lainnya.

Menguji reliabilitas dengan membandingkan nilai akar dari Average Variance Extracted (AVE) setiap konstruk dengan korelasi antara konstruk dengan konstruk lainnya.

\section{Tabel 3.}

Nilai AVE

\begin{tabular}{ccc}
\hline & AVE & Akar AVE \\
\hline Ekuitas Merek & 0.683731 & 0,826 \\
Negara Asal & 0.711045 & 0.843 \\
Niat Beli Kembali & 0.708377 & 0,841 \\
\hline
\end{tabular}

Sumber: Data diolah, 2018

Akar AVE pada Tabel 3. akan dibandingkan dengan nilai korelasi antar variavel bebas seperti ditunjukkan pada Tabel 4. 


\section{Tabel 4.}

Korelasi Antar Variabel Laten

\begin{tabular}{cccc}
\hline & Ekuitas Merek & Negara Asal & Niat Beli Ulang \\
\hline Ekuitas Merek & 1.000000 & & \\
Negara Asal & 0.724849 & 1.000000 & \\
Niat Beli Ulang & 0.724583 & 0.654186 & 1.000000 \\
\hline Sumber: Data diolah, 2018 & &
\end{tabular}

Sumber: Data diolah, 2018

Tabel 3. menunjukan bahwa akar AVE terendah adalah 0,826. Nilai korelasi antar konstruk terbesar pada Tabel 4. adalah 0,724. Dengan demikian semua nilai akar AVE jauh lebih besar daripada nilai korelasi antar konstruk sehingga dapat dikatakan bahwa data sudah reliabel.

Setelah model yang diestimasi memenuhi kriteria Outer Model, berikutnya dilakukan pengujian model structural (Inner model). Inner model menggambarkan hubungan antar variabel laten berdasarkan pada substantive theory. Dalam menilai model dengan PLS, dimulai dengan melihat $R$-squares untuk setiap variabel laten dependen. Hasil pengujian inner model dapat melihat hubungan antar konstruk dengan cara membandingkan nilai signifikansi dan $R$-square dari model penelitian (Ghozali, 2013)

\section{Tabel 5.}

Nilai $R$-Squares

\begin{tabular}{cc}
\hline & R Square \\
\hline $\begin{array}{c}\text { Ekuitas Merek } \\
\text { Negara Asal } \\
\text { Niat Beli Kembali }\end{array}$ & 0.525406 \\
\hline Niamber: Data dion & 0.560069 \\
\hline
\end{tabular}

Sumber: Data diolah, 2018

Nilai $R$-square variabel ekuitas merek sebesar 0,52 pada Tabel 5. dapat diintepretasikan bahwa 52\% variabilitas konstruk ekuitas merek dijelaskan oleh variabel negara asal sedangkan $48 \%$ variabel ekuitas merek dijelaskan oleh variabel di 
luar model. Demikian juga nilai R Square variabel niat beli ulang sebesar 0,56 yang menunjukkan bahwa 56\% variabilitas niat beli ulang dijelaskan oleh variabel negara asal sedangkan sisanya 44\% dijelaskan oleh variabel di luar model.

Signifikansi parameter yang diestimasi memberikan informasi yang sangat berguna mengenai hubungan antara variabel-variabel penelitian. Dasar yang digunakan dalam menguji hipotesis adalah nilai yang terdapat pada output path coefficients. Tabel 6. memberikan output estimasi untuk pengujian model struktural.

Tabel 6.

Path Coefficients (Mean, STDEV, T-Values)

\begin{tabular}{cccccc}
\hline & $\begin{array}{c}\text { Original } \\
\text { Sample (O) }\end{array}$ & $\begin{array}{c}\text { Sample } \\
\text { Mean (M) }\end{array}$ & $\begin{array}{c}\text { Standard } \\
\text { Deviation } \\
\text { (STDEV) }\end{array}$ & $\begin{array}{c}\text { Standard } \\
\text { Error } \\
\text { (STERR) }\end{array}$ & $\begin{array}{c}\text { T Statistics } \\
(\mid \mathbf{O} / \text { STERR|) }\end{array}$ \\
\hline $\begin{array}{c}\text { Ekuitas Merek } \\
\text {-> Niat Beli } \\
\text { Kembali }\end{array}$ & 0.527603 & 0.541591 & 0.141644 & 0.141644 & 3.724852 \\
$\begin{array}{c}\text { Negara Asal - } \\
\text { > Ekuitas } \\
\quad \text { Merek }\end{array}$ & 0.724849 & 0.727210 & 0.057092 & 0.057092 & 12.696077 \\
$\begin{array}{c}\text { Negara Asal - } \\
>\text { Niat Beli } \\
\text { Kembali }\end{array}$ & 0.271753 & 0.260627 & 0.133934 & 0.133934 & 2.029008 \\
\hline
\end{tabular}

Sumber: Data diolah, 2018

Pengujian terhadap hipotesis dalam metode PLS dilakukan dengan menggunakan simulasi terhadap setiap hubungan yang dihipotesiskan, dalam hal ini dilakukan metode bootstrap terhadap sampel. Metode bootstrap juga berfungsi untuk meminimalkan masalah ketidaknormalan data penelitian yang digunakan. Pada penelitian ini telah ditentukan sebelumnya nilai T-tabel dengan signifikansi $5 \%$ atau 0,05. Semua koefisien jalur pada Tabel 6. memiliki nilai T Statistik di atas 1,96 sehingga dinyatakan memiliki pengaruh yang signifikan. Pengujian masing-masing hipotesis dibahas pada sub berikut ini. 
I Komang Satria Warla Putra, Pengaruh Persepsi Negara...

Pengujian hipotesis pertama menunjukkan hasil bahwa hubungan antara negara asal dengan ekuitas merek adalah signifikan dengan T-statistik sebesar 12.696 (> 1,96). Nilai koefisien jalur sebesar 0,724 menunjukkan bahwa arah hubungan antara Negara asal dengan ekuitas merek adalah positif. Hipotesis $\mathrm{H}_{1}$ dalam penelitian ini yang menyatakan bahwa Negara asal berpengaruh terhadap ekuitas merek diterima.

Hasil ini sejalan dengan hasil penelitian yang dilakukan oleh Panda dan Misra (2014) terhadap produk tahan lama di India. Mengemukakan berdasarkan analisis hasil penelitian yang dihasilkan dari studi adalah terdapat pengaruh yang positif dan signifikan antara negara asal terhadap ekuitas merek. Hal serupa juga dikemukakan oleh Shahrokh dan Azodi (2013) dalam penelitiannya terhadap konsumen smartphone di Iran, terdapat pengaruh yang positif antara negara asal terhadap ekuitas merek, persepsi konsumen terhadap negara perakitan mencerminkan merek dari produk tersebut. Hasil penelitian lain yang dilakukan oleh Saydan (2013) dalam penelitianya mengemukakan bahwa variabel negara asal secara positif dan signifikan mempengaruhi ekuitas merek, citra suatu merek bergantung pada persepsi dari negara perakitannya, hal ini berarti semakin baik persepsi konsumen akan suatu negara maka semakin baik ekuitas merek produk dari negara tersebut.

Pengujian hipotesis kedua menunjukkan hasil bahwa hubungan antara ekuitas merek dengan niat beli kembali adalah signifikan dengan T-statistik sebesar 3,72 (> 1,96). Nilai koefisien jalur sebesar 0,527 menunjukkan bahwa arah hubungan antara ekuitas merek dengan niat beli kembali adalah positif. Hipotesis $\mathrm{H}_{2}$ dalam penelitian 
ini yang menyatakan bahwa ekuitas merek berpengaruh terhadap niat beli kembali diterima.

Hasil ini sejalan dengan hasil penelitian yang dilakukan oleh Chen (2011) dan Pather (2017) mengemukakan bahwa ekuitas merek secara signifikan mempengaruhi niat beli kembali, ini berarti bahwa semakin baik ekuitas merek yang dimiliki suatu produk, maka niat membeli kembali pelanggan terhadap produk tersebut semakin tinggi, lalu terdapat penelitian yang dilakukan oleh Said (2014) dalam penelitiannya yang dilakukan terhadap konsumen smartphone Nokia di Malaysia mengidentifikasi adanya hubungan antara negara asal dan niat beli kembali. Ekuitas merek merupakan salah satu kekuatan yang dimiliki perusahaan untuk menarik pelanggan kembali, semakin baik ekuitas merek yang mampu diciptakan oleh perusahaan maka semakin tinggi minat pelanggan untuk membeli kembali produk tersebut.

Pengujian hipotesis pertama menunjukkan hasil bahwa hubungan antara negara asal dengan niat beli kembali adalah signifikan dengan T-statistik sebesar $2.02(>1,96)$. Nilai koefisien jalur sebesar 0,271 menunjukkan bahwa arah hubungan antara Negara asal dengan ekuitas merek adalah positif. Hipotesis $\mathrm{H}_{3}$ dalam penelitian ini yang menyatakan bahwa Negara asal berpengaruh terhadap niat beli kembali diterima

Hasil ini sejalan dengan penelitian terdahulu oleh Filieri et al (2016) terhadap pengguna smartphone di China mengidentifikasi hubungan positif dan signifikan antara negara asal terhadap niat beli kembali hal ini berarti semakin baik citra negara suatu produk diciptakan maka niat beli kembali pelanggan akan meningkat. Terdapat penelitian yang dilakukan oleh Aulia (2016) terhadap konsumen Taiwan mengenai niat 
I Komang Satria Warla Putra, Pengaruh Persepsi Negara...

beli kembali produk kecantikan Korea mengidentifikasi bahwa negara asal secara positif dan signifikan akan mempengaruhi niat beli kembali pelanggan terhadap produk yang telah dibelinya dahulu.

Pengaruh langsung, pengaruh tidak langsung dan pengaruh total dari masingmasing variabel yang diteliti sebagai berikut :

\section{Tabel 7.}

Pengaruh Langsung, Pengaruh Tidak Langsung dan Pengaruh Total Negara Asal, Ekuitas Merek dan Niat Beli Kembali

\begin{tabular}{ccc}
\hline Tipe Pengaruh & Konstruk & $\begin{array}{c}\text { Standardized } \\
\text { Estimates }\end{array}$ \\
\hline \multirow{2}{*}{ Pengaruh Langsung } & Negara Asal - Ekuitas Merek & 0.725 \\
& Negara Asal - Niat Beli Kembali & 0.272 \\
& Ekuitas Merek - Niat Beli Kembali & 0.528 \\
Pengaruh Tak langsung & Negara Asal - Ekuitas Merek - Niat Beli & 0.382 \\
Pengaruh Total & Kembali & 0.654 \\
\hline
\end{tabular}

Sumber: Data diolah, 2018

Uji Sobel merupakan alat analisis untuk menguji signifikansi dari hubungan tidak langsung antara variabel eksogen dengan variabel endogen yang dimediasi oleh variabel intervening. Pada penelitian ini uji sobel dilakukan untuk mengetahui pengaruh variabel ekuitas merek dalam memediasi hubungan antara pengaruh variabel negara asal terhadap niat beli ulang smartphone merek Xiaomi di Kota Denpasar. Uji sobel dapat dirumuskan dengan menggunakan persamaan sebagai berikut:

$$
Z=\frac{a b}{\sqrt{a^{2} s_{b}^{2}+b^{2} s_{a}^{2}+s_{a}^{2} s_{b}^{2}}}
$$

Keterangan:

$Z$ = nilai kalkulasi sobel. 
$\mathrm{a}=$ koefisien regresi dari variabel eksogen $(\mathrm{X})$ terhadap variabel intervening (M).

$\mathrm{s}_{\mathrm{a}}=$ standard error dari $\mathrm{a}$.

$\mathrm{b}=$ koefisien regresi dari variabel intervening $(\mathrm{M})$ terhadap variabel endogen (Y). $\mathrm{s}_{\mathrm{b}}=$ standard error dari $\mathrm{b}$.

Bila nilai kalkulasi Z lebih besar dari 1,96 (dengan tingkat kepercayaan 95\%), maka variabel intervening dinilai secara signifikan memediasi parsial pengaruh antara variabel eksogen dengan variabel endogen. Uji sobel untuk signifikasi tidak langsung pengaruh negara asal terhadap niat beli ulang melalui ekutias merek. Secara rinci, perhitungan uji sobel dalam penelitian ini dapat dijelaskan sebagai berikut.

$$
\begin{aligned}
& Z=\frac{a b}{\sqrt{a^{2} s_{b}^{2}+b^{2} s_{a}^{2}+s_{a}^{2} s_{b}^{2}}} \\
& Z=\frac{0,3828}{\sqrt{0,725^{2} 0,141^{2}+0,528^{2} 0,057^{2}+0,057^{2} 0,141^{2}}} \\
& Z=\frac{0,3828}{\sqrt{0,5250,019+0,2780,003+0,0030,019}} \\
& Z=\frac{0,3828}{\sqrt{0,009+0,000834+0,000057}}=\frac{0,3828}{0,0994} \\
& Z=3,85
\end{aligned}
$$

Hasil uji sobel untuk signifikasi pengaruh tidak langsung variabel negara asal terhadap niat beli ulang melalui ekuitas merek mendapatkan $\mathrm{Z}$ yakni 3,85 lebih besar dari 1,96. Hasil ini menyatakan bahwa variabel ekuitas merek dinilai secara signifikan memediasi parsial pengaruh antara variabel negara asal dengan variabel niat beli ulang.

Berdasarkan hasil penelitian terdahulu yang oleh Ghalandari et al., (2012) yang menunjukkan bahwa negara asal tidak berpengaruh langsung terhadap niat beli kembali 
dan Permadi (2011) dalam penelitian yang dilakukannya di Solo terhadap elektronik buatan Jepang menyatakan peran ekuitas merek dalam memediasi negara asal terhadap niat beli kembali, hal ini berarti ekuitas merek mampu sebagai variabel mediasi untuk memperkuat hubungan antara negara asal terhadap niat beli kembali. Hasil ini sejalan dengan hasil penelitian yang dilakukan oleh Ulfah (2017) terhadap pengguna smartphone merek Lenovo di Kota Denpasar juga menemukan bahwa ekuitas merek memiliki peran yang signifikan dalam memediasi negara asal terhadap niat beli kembali.

Implikasi dari hasil penelitian mencakup dua hal, yaitu implikasi teoritis dan praktis. Implikasi teoritis berhubungan dengan kontribusi bagi perkembangan teori tentang peran ekuitas merek memediasi pengaruh negara asal terhadap niat beli kembali sedangkan implikasi praktis berkaitan dengan kontribusi penelitian terhadap niat beli kembali pelanggan smartphone merek Xiaomi yang berada di Kota Denpasar.

Berdasarkan hasil penelitian yang dilakukan menunjukan Penelitian ini telah mampu mengkonfirmasi sekaligus memperkuat pengaruh negara asal dan ekuitas merek dalam kaitannya dengan niat beli kembali. Hasil dari model teoritik tersebut menjelaskan bahwa berdasarkan hasil penelitian mengenai pengaruh negara asal, secara langsung mempengaruhi ekuitas merek, hal ini berarti semakin baik citra suatu negara tempat produk diciptakan maka semakin baik citra merek yang dimiliki produk tersebut. Penelitian ini menegaskan konsep dari beberapa penelitian sebelumnya yang dilakukan oleh Panda dan Misra (2014), Shahrokh dan Azodi (2013) serta Saydan (2013) menyatakan bahwa citra yang baik mengenai negara asal akan berdampak 
positif terhadap ekuitas merek suatu produk. Hal ini berarti bahwa hasil studi ini memperkuat teori tentang hubungan antara variabel negara asal dan ekuitas merek.

Berdasarkan hasil penelitian mengenai pengaruh ekuitas merek, secara langsung mempengaruhi niat beli kembali, hal ini berarti semakin sebuah perusahaan memiliki citra merek yang baik maka semakin tinggi minat pelanggan untuk membeli kembali produk dari merek tersebut. Penelitian ini menegaskan konsep dari beberapa penelitian sebelumnya yang dilakukan oleh Chen (2011) dan Pather (2017) serta Said (2014) yang menyatakan bahwa ekuitas merek yang baik dari suatu produk akan berdampak positif terhadap niat pelanggan untuk membeli kembali. Hal ini berarti bahwa hasil studi ini memperkuat teori tentang hubungan antara variabel ekuitas merek dengan niat beli kembali.

Berdasarkan hasil penelitian mengenai pengaruh negara asal, secara langsung mempengaruhi niat beli kembali dan juga secara tidak langsung melalui ekuitas merek akan mempengaruhi niat beli kembali, hal ini berarti semakin baik citra negara perakitan produk maka akan mempengaruhi niat beli kembali pelanggan. Penelitian ini menegaskan konsep dari beberapa penelitian sebelumnya mengenai negara asal yang dilakukan oleh Filieri et al., (2016) dan Aulia (2016) dalam penelitianya menyatakan bahwa negara asal akan berpengaruh positif dan signifikan terhadap niat beli kembali. Hal ini berarti bahwa hasil studi ini memperkuat teori tentang hubungan antara variabel negara asal pasar terhadap niat beli kembali.

Berdasarkan hasil penelitian ini diharapkan digunakan sebagai masukan bagi perusahaan maupun penjual produk smartphone merek Xiaomi sehingga dapat 
meningkatkan niat pembelian kembali dari pelanggan dengan memperhatikan beberapa hal seperti berikut tampak bahwa citra negara asal China semakin baik di bidang teknologi smartphone. Pengetahuan mengenai persepsi negara asal penting diperhatikan oleh perusahaan ataupun penjual produk smartphone merek Xiaomi. Berdasarkan hasil penelitian yang telah dilakukan menunjukan apabila perusahaan memahami citra negara asal, persepsi pelanggan mengenai negara perakitan produk akan berdampak positif dalam meningkatnya niat beli kembali pelanggan terhadap produk yang pernah dibelinya.

Pengetahuan mengenai ekuitas merek penting dimiliki oleh perusahaan ataupun penjual produk smartphone merek Xiaomi karena berdasarkan hasil penelitian yang telah dilakukan menunjukan apabila perusahaan memahami ekuitas merek dimaksud disini adalah citra, pandangan konsumen tentang suatu merek baik dari nama, logo, kualitas produk dari merek tersebut akan berdampak positif dalam meningkatnya niat beli kembali pelanggan ke produk yang pernah dibelinya.

Berdasarkan penelitian yang telah dilakukan ditemukan beberapa keterbatasan dalam penelitian ini. Hanya sebatas meneliti mengenai pengaruh negara asal dan ekuitas merek terhadap niat beli kembali di Kota Denpasar serta hasil penelitian ini tidak dapat di generalisir maupun tidak dapat digunakan pada Kota lain. Diharapkan penelitian selanjutnya dapat menggunakan maupun menambahkan variabel lain sebagai alat analisisnya selain hal tersebut. Penelitian ini hanya sebatas pada pelanggan smartphone merek Xiaomi yang berada di Kota Denpasar. 


\section{SIMPULAN DAN SARAN}

Berdasarkan tujuan penelitian, rumusan masalah dan hasil penelitian dengan pembahasan yang telah dipaparkan, maka dapat diambil kesimpulan bahwa negara asal berpengaruh positif dan signifikan terhadap ekuitas merek smartphone merek Xiaomi. Hal ini berarti semakin baik citra negara asal produk smartphone merek Xiaomi yang dimiliki oleh perusahaan maka akan semakin baik ekuitas smartphone merek Xiaomi di Kota Denpasar.

Ekuitas merek berpengaruh positif dan signifikan terhadap niat beli kembali produk smartphone merek Xiaomi di Kota Denpasar. Hal ini berarti semakin baik citra merek yang mampu ditunjukkan oleh perusahaan produk smartphone merek Xiaomi maka niat beli kembali pelanggan produk smartphone merek Xiaomi di Kota Denpasar akan meningkat.

Negara asal berpengaruh positif dan signifikan terhadap niat beli kembali pelanggan smartphone merek Xiaomi di Kota Denpasar. Hal ini berarti semakin baik citra negara asal yang dimiliki oleh perusahaan smartphone merek Xiaomi maka akan meningkatkan niat beli kembali pelanggan smartphone merek Xiaomi di Kota Denpasar.

Ekuitas merek mampu memediasi citra negara asal terhadap niat beli kembali produk smartphone merek Xiaomi di Kota Denpasar. Hal ini berarti semakin baik persepsi negara asal konsumen terhadap smartphone merek Xiaomi maka akan meningkatkan niat beli ulang smartphone merek Xiaomi. Selain secara langsung, 
I Komang Satria Warla Putra, Pengaruh Persepsi Negara...

persepsi negara asal juga mampu meningkatkan niat beli ulang lebih besar melalui ekuitas merek smartphone merek Xiaomi di Kota Denpasar.

Berdasarkan hasil penelitian maka penulis memberikan saran yang diharapkan dapat membantu para pelaku bisnis smartphone merek Xiaomi di Kota Denpasar serta para peneliti selanjutnya yaitu nilai koefisien regresi ekuitas merek terhadap niat beli ulang lebih besar. Ternyata secara langsung variabel ekuitas merek memberikan pengaruh lebih besar, maka yang perlu diperhatikan bagaimana mempengaruhi ekuitas merek.

Deskripsi data hasil penelitian menunjukkan hasil rata-rata yang baik, diharapkan perusahaan mampu meningkatkan kembali agar menjadi lebih baik.

Bagi peneliti selanjutnya, diharapkan untuk melakukan penelitian dengan cakupan yang lebih luas, menambah variabel-variabel lain diluar penelitian ini serta diharapkan mampu menambah referensi terhadap variabel yang akan diteliti.

\section{REFERENSI}

Aaker, David. 2014. Aaker on Branding. : 20 Principles That Drive Success. United States : Morgan James

Abdi, Yonathan Tedja. 2010. Pengaruh Brand Image dan Negara asal Terhadap Kepuasan dan Loyalitas Konsumen Pada Produk TV Samsung di Surabaya. Jurnal Mitra Ekonomi dan Manajemen Bisnis, 3(1), h:75-86

Andy, P. 2017. Xiaomi vs Samsung Bagus Mana. Diterima dari https://teknorus.com. Diakses 27 Desember 2017

Chen, Han-Shen and Tsuifang Hsieh. 2011. A Study of Antecedents of Customer Repurchase Behaviors in Chain Store Supermarket. Journal of International Management Studies. 6(3)

Dehdashti Shahrokh, Zohreh and Arman Deilami Azodi. 2013. The Effect of Country of Image on Brand Equity and Purchase Intention. J. Appl. Environ. Biol. Sci., 3(12), pp: 52-61 
Filieri, Raffaele, Wenshin Chen, and Bidit Lal Dey. 2017. The importance of enhancing, maintaining and saving face in smartphone repurchase intention of Chinese early adopters: An exploratory study. Information Technology \& People, 30(3), pp: 629-652

Ghozali, Imam. 2013. Analisis Multivariate Dengan Program SPSS 21 Update PLS Regresi. BP Universitas Diponegoro

Hussein, Ananda Sabil. 2015. Penelitian Bisnis dan Manajemen Menggunakan Partial Least Squares (PLS) dengan smartPLS 3.0.

Kotler, Philip and Kevin Lane Keller. 2012. Marketing Management. 14th Edition. Prentice Hall

Kumar Panda , Rajeev and Siddharth Misra. 2014. Impact of Country Of Origin Image on Brand Equity: A Study on Durable Products in India. Social and Behavioral Sciences, 150, pp: $494-499$

Lin, Yun-Tsan, Shui-Chuan Chen and Chuan-Sheng Hung. 2011. The impacts of brand equity, brand attachment, product involvement and repurchase intention on bicycle users. African Journal of Business Management, 5(14), pp. 5910-5919

Moslehpour, Massoud, Wing-Keung Wong, Kien Van Pham and Carrine K. Aulia, 2017. Repurchase intention of Korean beauty products among Taiwanese consumers. Asia Pacific Journal of Marketing and Logistics, 29(3), pp: 1-24

Pather, Pravenshi. 2017. Brand Equity as a Predictor of Repurchase Intention of Male Branded Cosmetic Products in South Africa. Business \& Social Science Journal (BSSJ). 2(1), pp.1-23

Permadi, Yusuf Setia. 2011. Pengaruh Citra Negara asal Terhadap Niat beli kembali yang Dimediasi oleh Ekuitas merek (studi kasus pada pengguna produk elektronik buatan Jepang di kota Solo). Skripsi. Fakultas Ekonomi Universitas Sebelas Maret Surakarta

Pratomo, Gito Yudha. 2014, Agustus 27. Redmi 1S, Ponsel Pertama Xiaomi di Indonesia. Diterima dari https://www.cnnindonesia.com. Diakses 25 Agustus $\underline{2017}$

Said, Hamad. 2014. Mobile Phone Brand Loyalty and Repurchase Intention. European Journal of Business and Management, 6(26), pp: 69-72

Sanyal, Shamindra Nath and Saroj Kumar Datta. 2011. The effect of country of origin on brand equity: an empirical study on generic drugs. The Journal of Product and Brand Management, 20(2), pp:130-140

Saydan, Reha. 2013. Relationship between Country of Origin Image and Brand Equity: An Empirical Evidence in England. Market International Journal of Business and Social Science, 4(3), pp: 78-88

Setyaningsih, Rahmawati, Suyudi Mangunwihardjo dan Harry Soesanto. 2007. Aanalisis Faktor-Faktor yang Mempengaruhi Ekuitas Merek untuk Meningkatkan Minat Beli Ulang (Srudi Kasus pada Kedai Kopi DÔME di Surabaya). Jurnal Studi Manajemen dan Organisasi. 4(2), h: 30-43 
I Komang Satria Warla Putra, Pengaruh Persepsi Negara...

Ulfah, Qolbina dan I Gusti Ayu Ketut Giantari. 2017. Peran Ekuitas merek dalam Memediasi Pengaruh Negara asal Image Terhadap Niat beli kembali. E-Jurnal Manajemen Unud, 6(6),h: 2846-2875

Yasin, Norjaya Mohd, Mohd Nasser Noor, Osman Mohamad. 2012. Does image of country of origin matter to brand equity?. Journal of Product \& Brand Management. 16(1), pp: 38-48

Yoo, Boonghee, Naveen Donthu and Sungho Lee. 2000. An Examination of Selected Marketing Mix Elements and Brand Equity. Journal of the Academy of Marketing Science. 28(2), pp: 195-211 